\title{
Social media en smartphones als verklaring voor de daling in jeugdcriminaliteit?
}

\section{F. Weerman*}

Een van de mogelijke invalshoeken om de opmerkelijke daling in de jeugdcriminaliteit te verklaren, betreft de ontwikkeling op het terrein van computers, internet en media. In het inleidende artikel van dit nummer noemen Berghuis en De Waard 'veranderingen in mediagebruik en vrije tijd' als een van de verklaringen, met name de snelle technologische ontwikkeling op dit terrein. Ook Van der Laan e.a. gaan in hun bijdrage uitgebreid in op digitalisering en social media. 'Gamen en internetten zouden jongeren wel eens uit de criminaliteit kunnen houden', meldde De Telegraaf eerder op basis van gesprekken met vertegenwoordigers van de rechtspraak en het Openbaar Ministerie ${ }^{1}$. Ook in een recent rapport over de duiding van de daling in jeugdcriminaliteit (Van Ham \& Ferwerda 2016) noemen meerdere deskundigen en betrokkenen de toename van online activiteiten als mogelijke verklaring, in combinatie met een scala aan andere mogelijke oorzaken. De aandacht voor ontwikkelingen in online activiteiten is overigens vrij recent. In eerdere artikelen over de daling van de jeugdcriminaliteit in Nederland, en over de meer algemene daling in criminaliteitscijfers die zich al vanaf 2002 voordoet in de westerse wereld, ontbreekt de 'media en internet'-verklaring nog en wordt vooral gekeken naar economische en demografische trends, ontwikkelingen in de rechtshandhaving, de opkomst van situationele preventie, en de neergang van alcoholgebruik en drugsverslaving (zie onder meer Bervoets e.a. 2013; Farrell e.a. 2011; Van der Laan \& Weijters 2015; Vollaard e.a. 2009; Weerman e.a. 2015a). Kennelijk zijn de ontwikkelingen zo snel gegaan, dat het belang daarvan pas nu is doorgedrongen in de wetenschappelijke beschouwingen.

* Prof. dr. Frank Weerman is bijzonder hoogleraar Jeugdcriminologie binnen de sectie Criminologie van de Erasmus School of Law in Rotterdam. Hij is tevens senior onderzoeker bij het Nederlands Studiecentrum Criminaliteit en Rechtshandhaving te Amsterdam.

1 'Oorzaken gezocht voor daling jeugdstrafzaken', De Telegraaf 30 november 2013. 
In deze bijdrage zal ik dieper ingaan op de hypothese dat de snelle veranderingen op het terrein van internet, met name de opkomst van social media en smartphones, hebben bijgedragen aan de daling. Om te beginnen constateer ik dat er opmerkelijke parallellen te zien zijn tussen de recente ontwikkelingen in de jeugdcriminaliteit en de veranderingen met betrekking tot het gebruik van social media en smartphones. Vervolgens tracht ik een inhoudelijke duiding te geven van een eventueel verband. Ik bespreek drie processen die mogelijk een rol kunnen hebben gespeeld: veranderingen die te maken hebben met de tijdsbesteding van jongeren, veranderingen die te maken hebben met de psychologische en sociale functies van social media, en veranderingen in de aard en zichtbaarheid van criminele activiteiten. Tot slot plaats ik enkele kanttekeningen bij de mogelijke verklaringen en geef ik aan op welke wijze nader onderzoek meer inzicht zou kunnen bieden in deze materie.

\section{Parallelle ontwikkelingen}

Elders in dit themanummer zijn de opmerkelijke ontwikkelingen in de jeugdcriminaliteit al uitgebreid beschreven. Kort gezegd komt het erop neer dat in Nederland de geregistreerde jeugdcriminaliteit na een jarenlange stijging vanaf het begin van de jaren zestig van de vorige eeuw (met enige fluctuaties) sinds 2007 een opmerkelijke daling laat zien. In 2015 is het aantal geregistreerde minderjarige verdachten per 100.000 meer dan gehalveerd ten opzicht van 2007. De daling is ook zichtbaar in de zelfrapportagegegevens uit de Monitor Jeugdcriminaliteit van het WODC (Van der Laan \& Goudriaan 2016), maar is daar aanmerkelijk minder pregnant. Opvallend is het internationale karakter van de daling. In hun inleidende artikel presenteren Berghuis en De Waard gegevens voor verschillende Angelsaksische landen en voor Duitsland, waar de geregistreerde jeugdcriminaliteit ook opmerkelijk is gedaald. Aanvullende gegevens van onder meer Eurostat (zie ook de bijdrage van Van der Laan e.a.) laten zien dat ook in veel andere (maar niet alle) westerse landen zo'n daling is waar te nemen. ${ }^{2} \mathrm{Zo}$ is de jeugdcriminaliteit eveneens sterk gedaald in België en de meeste andere landen in Noordwest- en Centraal-Europa. 
Nog opmerkelijker is de timing van de daling. In de meeste landen is het niveau min of meer stabiel tot aan 2007 of iets later, en daarna zet een gestage afname in die nog steeds doorgaat. Deze crossnationale overeenkomst in timing suggereert dat de oorzaken van de daling niet (of niet primair) moeten worden gezocht op nationaal niveau. Dat is overigens vergelijkbaar met de meer algemene afname in geregistreerde criminaliteit die al langer aan de gang is in de westerse wereld (zie bijv. Tonry 2014; Weerman e.a. 2015a).

Welke internationale oorzaken zouden in aanmerking kunnen komen? In het inleidende artikel van dit nummer is reeds een aantal mogelijkheden aan de orde gekomen. Bij het zoeken naar de meest plausibele verklaring is het echter interessant eens wat nader te kijken naar het tijdstip waarop de daling inzette. Welke internationale gebeurtenis of trend, met name relevant voor jongeren, kunnen we signaleren rond 2007 ? Een kleine zoektocht wijst uit dat daarvoor de opkomst van de smartphonetechnologie en de doorgroei van social media de meest voor de hand liggende kandidaten zijn.

Een eerste belangrijke ontwikkeling is de opkomst van social networksites, zoals Facebook, Instagram en (in Nederland) Hyves. Facebook begon op kleine schaal in 2004 op een Amerikaanse campus, maar beleefde vanaf 2008 een wereldwijde opmars (in Nederland iets later), die internationaal nog steeds voortgaat. ${ }^{3}$ In Nederland begon vanaf 2005 Hyves populair te worden, ruim voor de opmars van Facebook. In die tijd waren er ook al enkele andere social network-sites en tools, die inmiddels zijn verdwenen, zoals CU2, Sugababes, MSN Messenger en ICQ (zie Valkenburg 2014). Het gebruik van Hyves kwam in 2006 echt op gang en piekte in 2009. In 2007 en 2008 was Hyves 'website van het jaar'. Ook andere social media begonnen hun opmars rond of na 2007. YouTube begon in 2005 en raakte echt in zwang vanaf 2006), Twitter begon in 2006 en groeide vooral vanaf 2010 (maar is nu over het hoogtepunt heen); Instagram startte in 2010 en Snapchat in 2011, en deze vormen van social media zijn op dit moment onder jongeren bijna net zo populair als YouTube en Facebook (Turpijn e.a. 2015). $\mathrm{Al}$ met al zijn er steeds meer mogelijkheden gekomen om gebruik te maken van social media, en de populariteit daarvan is dan ook gestaag toegenomen in de afgelopen tien jaar (zie figuur 8 in de bijdrage van Van der Laan e.a.). 
Een andere ontwikkeling is de opmars van smartphones. Al langer bestonden er geavanceerde mobiele telefoons, maar in 2007 kwam de iPhone op de markt, die als een van de eerste gebruik maakte van touchscreens. Het bezit en gebruik van smartphones is sinds die tijd enorm gestegen. Vooral vanaf 2010 steeg het (wereldwijde) bezit van smartphones sterk, zoals figuur 3 uit het artikel van Berghuis en De Waard al liet zien. Ook het gebruik van smartphones en tablets om te internetten is sterk gestegen in de afgelopen jaren, met name vanaf $2011^{4}$ (zie de bijdrage van Van der Laan e.a. in dit nummer). Heden ten dage is de smartphone niet meer weg te denken uit het straatbeeld, en vormt deze een veelgebruikte bron van vermaak, afleiding en communicatie. Smartphones bieden bovendien ook mobiel toegang tot bovengenoemde social media, en daarmee hebben jongeren ook buitenshuis hiertoe toegang gekregen. Dat is een heel andere situatie dan in de begintijd van social media en chatkanalen zoals MSN en CU2, waar jongeren moesten inbellen via de telefoonlijn. Social media en internet zijn steeds toegankelijker en goedkoper geworden.

Al met al zijn de smartphone en de daaraan verbonden social media onlosmakelijk verbonden geraakt aan het dagelijkse leven van jongeren en aan hun sociale interactie. Het totale gebruik van social media en smartphones is sterk en gestaag toegenomen vanaf ongeveer 2007. Die ontwikkelingen verlopen opmerkelijk parallel met de daling van de geregistreerde jeugdcriminaliteit in een groot deel van de westerse landen.

\section{Verandering in tijdsbesteding als verklarend proces}

Een van de mogelijke gevolgen van de opkomst van social media en smartphones is een gewijzigd vrijetijdspatroon van jongeren. Van belang is om deze verklaring nader in te vullen. Om welk aspect van tijdsgebruik gaat het dan? En waarom zou tijdsbesteding gerelateerd zijn aan jeugdcriminaliteit?

Een aanknopingspunt is de wetenschappelijke literatuur over delinquent gedrag en tijd die met leeftijdsgenoten wordt doorgebracht. Criminoloog Mark Warr wees erop dat tijdens de adolescentie jongeren steeds meer tijd gaan doorbrengen met hun leeftijdsgenoten, en dat er 
tegelijkertijd sprake is van een piek in crimineel gedrag in deze leeftijdsfase (Warr 1993). Op zichzelf hoeft de omgang met leeftijdsgenoten geen probleem te zijn; sociale interacties zijn juist van groot belang voor het welzijn van jongeren en voor hun psychosociale ontwikkeling. Er zijn echter allerlei groepsprocessen die ervoor kunnen zorgen dat jongeren onder leeftijdsgenoten grenzen overschrijden die ze in hun eentje zouden respecteren. Jongeren conformeren zich aan anderen uit angst voor gek te staan, omdat ze mee willen doen met anderen en loyaal willen zijn aan hun vrienden, om aanzien en erkenning te krijgen. Groepen zorgen voor een gevoel van anonimiteit, voor het vervagen van de eigen verantwoordelijkheid, en ze creëren een eigen 'moreel universum' (Warr 2002).

Volgens criminoloog Wayne Osgood hangt vooral de mate waarin jongeren ongestructureerd samen zijn zonder toezicht ('unstructured socializing in the absence of authority figures') - eenvoudiger gezegd: rondhangen - samen met een verhoogde kans om delicten te plegen (Osgood e.a. 1996; Osgood \& Anderson 2004). Als jongeren zich vaak in zulke situaties bevinden, verhoogt dat de kans op verleidingen en gelegenheden voor problematisch gedrag. Groepen jongeren die rondhangen, kunnen het wel waarderen als er iets bijzonders gebeurt en fungeren zo als waarderend publiek voor avontuurlijk en grensoverschrijdend gedrag. De aanwezigheid van leeftijdsgenoten maakt het plegen van eventuele delicten gemakkelijker omdat er mededaders beschikbaar zijn. Afwezigheid van ouders en andere autoriteiten betekent dat er geen toezicht is en dat delinquente gedragingen niet worden tegengehouden door volwassenen. En het ongestructureerde karakter van rondhangen betekent dat er simpelweg tijd beschikbaar is voor delinquent gedrag.

Recent onderzoek laat zien dat tijd met vrienden vooral onder bepaalde voorwaarden leidt tot meer delinquent gedrag. Als er veel wordt rondgehangen met meerdere leeftijdsgenoten, die niets anders doen dan 'socializen' (of 'chillen'), als er geen bekende volwassenen aanwezig zijn én als jongeren samen zijn in de publieke ruimte (op straat, in een park, of in een ander openbaar gebied), dan verhoogt dit de kans op betrokkenheid bij jeugdcriminaliteit substantieel (Weerman e.a. 2015b; Hoeben \& Weerman 2014). Het effect wordt nog eens vergroot als er delinquente vrienden aanwezig zijn en jongeren rondhangen in buurten met weinig sociale cohesie (Hoeben 2016). 
De opkomst van social media en computergames heeft er naar alle waarschijnlijkheid toe geleid dat jongeren aanmerkelijk minder tijd zijn gaan doorbrengen met rondhangen op straat, de meest criminogene vorm van rondhangen. Voor een belangrijk deel vinden online activiteiten thuis achter een computer plaats, bij vrienden of op school. Tegelijkertijd is het internet mobiel bereikbaar geworden door de opkomst van smartphones. Echter, dit heeft er waarschijnlijk toe geleid dat de aandacht van jongeren die op straat rondhangen, is verschoven van wat er op straat gebeurt naar wat er op het beeldscherm van de telefoon te zien is. Kortom, het is aannemelijk dat jongeren zowel binnenshuis als buitenshuis steeds meer tijd zijn gaan besteden aan games, filmpjes, social media en andere online activiteiten en minder aan het pure rondhangen met leeftijdsgenoten op straat. Zoals door Berghuis en De Waard reeds is vermeld, zijn hiervoor aanwijzingen te vinden in het tijdsbestedings- en mediaonderzoek van het SCP dat regelmatig wordt uitgevoerd (Sonck \& De Haan 2015). Ook uit CBS- en SCP-gegevens komt naar voren dat jongeren en mensen in het algemeen in toenemende mate 'online zijn' met mobiele apparatuur, laptops of tablets (CBS 2016; Sonck \& De Haan 2015). In een CBSonderzoek uit 2015 bleek dat meer dan de helft van de jongeren rapporteert gemiddeld 1 tot 3 uur per dag te besteden aan social media, en een kwart meer dan 3 uur (Kloosterman \& Van Beuningen 2015). Minder duidelijk is in hoeverre het rondhangen (of 'unstructured socializing') onder Nederlandse jongeren daadwerkelijk is afgenomen. Hier is niet expliciet naar gevraagd in het tijdsbestedingsonderzoek. We weten wel dat het aantal problematische jeugdgroepen op straat dat door de politie wordt gesignaleerd sterk is afgenomen (zie o.a. Ferwerda \& Van Ham 2015), maar of dit ook door te trekken is naar alle jeugdgroepen en jongeren in het openbaar is niet onderzocht. Behalve het doorbrengen van meer tijd achter beeldschermen en waarschijnlijk minder tijd buitenshuis met leeftijdsgenoten, zal ook de aard van de activiteiten tijdens het rondhangen met leeftijdsgenoten zijn veranderd. Nog steeds zal het meeste van wat er dan gebeurt ongestructureerd zijn. Maar in plaats van kletsen en rondkijken of er nog wat te beleven valt, zal de aandacht vaak gevestigd zijn op de meegebrachte smartphones. In groepen jongeren is een substantieel deel van de tijd de aandacht gericht op het beeldscherm. Dat wil overigens niet zeggen dat er geen sprake is van sociale interactie. Wat wordt bekeken en gedaan op internet wordt gezamenlijk bekeken en bespro- 
ken. Maar de afleidingen en belevenissen worden dan minder op straat gevonden, en meer op het internet.

Meer algemeen heeft de smartphone een centrale rol gekregen in het dagelijkse openbare leven, ook onder volwassenen. Tijdens de verloren momenten in het openbaar vervoer en in de wachtrij grijpen velen naar hun mobiele apparaat. Dat geldt wellicht nog in sterkere mate voor jongeren. Waar in vroeger tijden de vrijetijdsbesteding van sommige jongeren nog kon worden gekarakteriseerd met 'rondhangen als tijdverdrijf' (Hazekamp 1985), zou tegenwoordig eerder gesproken moeten worden van 'smartphones als bezigheid'.

\section{De psychologische en sociale betekenis van social media als verklarend proces}

Behalve een verandering in tijdsbesteding en activiteitenpatronen van jongeren, heeft de opkomst van social media en smartphones nog andere, wellicht nog diepgaandere, effecten gehad. Die hebben te maken met de functies die social media en smartphones vervullen in het leven van adolescenten.

Kietzmann e.a. (2011; zie ook Van den Broek 2013) onderscheiden zeven verschillende functies of 'blokken' binnen social media:

- het kenbaar maken van de eigen identiteit en de kenmerken die daarbij horen: niet alleen basale gegevens, maar ook meer persoonlijk zaken zoals interesses, meningen en gevoelens. Ook met de berichten die worden gepost, kan iemand zichzelf presenteren als een bepaald persoon;

- conversatie, het voeren van gesprekken of het op andere manier communiceren via de kanalen van social media. WhatsApp is een vorm van social media die hiervoor primair is ingericht;

- het delen van belevenissen en gebeurtenissen met elkaar, via het plaatsen van content zoals blogs, foto's en video's;

- het kenbaar maken van de online aanwezigheid en de locatie waar iemand zich daadwerkelijk bevindt of heeft bevonden;

- het leggen en opbouwen van zakelijke en persoonlijke relaties en dit kenbaar maken aan andere gebruikers - elkaars Facebookvriend zijn of volger op Twitter bijvoorbeeld; 
- het vormen van groepen of gemeenschappen, om een gezamenlijk doel te behartigen of een interesse te bespreken, of om simpelweg de communicatie te vergemakkelijken;

- het verkrijgen van reputatie en status via social media. Via 'likes', beoordeling, aantallen views, retweets en volgers kunnen gebruikers beoordelen hoe populair en veelbekeken andere gebruikers zijn.

Andere onderzoekers onderscheiden allerlei affordances van social media, gebruiksmogelijkheden of meerwaardes (Valkenburg 2014; Bucher \& Helmond 2017), zoals zichtbaarheid, veranderbaarheid, toegankelijkheid en bereikbaarheid. Social media zijn onder meer extra aantrekkelijk voor jongeren omdat ze veel autonomie en controle geven over wat iemand wil communiceren, wanneer en met wie. Social media kunnen jongeren helpen bij het ontwikkelen van de eigen identiteit en vergroten bij veel jongeren het zelfvertrouwen (Valkenburg 2014).

Kortom, social media vervullen allerlei sociale en psychologische functies die juist tijdens de adolescentiefase bijzonder interessant en aantrekkelijk zijn. Social media zijn voor jongeren een plek geworden om de eigen identiteit vorm te geven en kenbaar te maken, om ergens bij te horen en om erkenning en waardering te krijgen van en te geven aan leeftijdsgenoten. Met andere woorden, social media en het internet bieden mogelijkheden om een aantal belangrijke behoeften van jongeren te bevredigen: de behoefte aan erkenning en waardering van leeftijdsgenoten, de behoefte aan identiteitsvorming en exploratie, en de behoefte aan vermaak. Dat jongeren de waardering en erkenning die zij krijgen via social media belangrijk vinden, blijkt ook uit het recente CBS-onderzoek naar socialmediagebruik onder jongeren (Kloosterman \& Van Beuningen 2015). Ongeveer de helft van de ondervraagde jongeren geeft aan een goed gevoel te krijgen als anderen posts van hen liken, retweeten of sharen, en als ze veel contacten hebben op social media.

Social media en online activiteiten hebben natuurlijk ook hun schaduwzijden. In de literatuur worden meerdere risico's en problemen genoemd: internetverslaving (of beter: compulsief gamen of socialmediagebruik), cyberpesten, sexting, 'Facebook depression', enzovoort (O’Keeffe \& Clarke-Pearson 2011; Kerstens \& Stol 2012; Schoenmakers e.a. 2015; Valkenburg 2014). Voor een minderheid van de jongeren zijn social media helemaal niet zo prettig. Bij hen worden gevoe- 
lens van eenzaamheid vergroot en doen negatieve ervaringen op internet juist afbreuk aan hun zelfwaardering (Valkenburg 2014). De meerderheid van de jongeren lijkt echter op een gezonde manier om te gaan met de mogelijkheden die internet en social media hun bieden, en zij gebruiken deze als versterking en aanvulling op hun offline contacten.

Interessant is dat verschillende positieve functies van social media en online activiteiten overlappen met de beloningen die zijn verbonden aan het plegen van jeugdcriminaliteit. Bij een groot deel daarvan gaat het immers niet puur om het gewin, maar ook en vaak primair om sociale en immateriële beloningen. Een opmerkelijk kenmerk van jeugdcriminaliteit is immers dat die vaak plaatsvindt in het gezelschap van anderen (Weerman 2001; Hakkert e.a. 1998; Bernasco e.a. 2013), zelfs wanneer dat voor de uitvoering helemaal niet nodig is. Dat kenmerk van jeugdcriminaliteit suggereert dat het ook gaat om het groepsaspect en de immateriële beloningen die dat met zich meebrengt. In veel gevallen levert het plegen van delicten in groepsverband erkenning op van mededaders en waardering van min of meer delinquente leeftijdsgenoten (zie ook het artikel van Ferwerda \& Van Ham in dit nummer).

Andere mogelijke immateriële beloningen van jeugdcriminaliteit zijn een verhoogd gevoel van autonomie, competentie (jongeren die op school niet mee kunnen komen, maar wel goed zijn in het plegen van delicten) en verbondenheid (met mededaders of een problematische jeugdgroep). Het gaat hierbij om primaire psychologische behoeften, voor zowel kinderen en jongeren als volwassenen (Deci \& Ryan 1975, 2008). Tot slot is een belangrijke immateriële beloning van jeugdcriminaliteit ook het beleven van iets spannends en het hebben van afleiding en plezier in een leven dat wordt gekenmerkt door verplichtingen thuis en op school (zie ook Warr 2002).

Jongeren hebben met de opkomst van social media dus veel meer mogelijkheden gekregen om in de sociale behoeften aan verbondenheid, erkenning en waardering te voorzien, om een eigen identiteit en levensstijl te ontwikkelen, maar ook om simpelweg vermaakt te worden. Delinquent gedrag is daarom voor sommige jongeren misschien minder nodig als middel om ergens bij te horen, als manier om grenzen te verkennen, om status en waardering te krijgen en om wat te beleven - dat kan nu ook deels via het gebruik van social media en smartphones. Uiteraard zal er een categorie jongeren blijven voor wie 
social media en smartphones nooit voldoende vervanging zullen bieden voor de verleiding en aantrekkingskracht van criminaliteit. Ook is dit natuurlijk geen panacee voor de cumulatie aan problemen en risico's waarmee ernstig delinquente jongeren vaak te kampen hebben. Maar voor sommige jongeren en sommige delicten kan het bezig zijn met social media wel veel wegnemen van de noodzaak die jongeren in de adolescentie voelen om de wet te overtreden als onderdeel van het proces van volwassenwording.

\section{Veranderingen in de zichtbaarheid van jeugdcriminaliteit als proces}

De opkomst van social media en meer algemeen het internet heeft niet alleen positieve gevolgen gehad voor het leven van jongeren, maar ook geleid tot de opkomst van nieuwe problemen en andere vormen van jeugdcriminaliteit. Sociale en economische interacties spelen zich tegenwoordig voor een belangrijk deel online af, en in het verlengde daarvan ook veel criminele handelingen (Van der Bruggen 2015). Ook jongeren maken zich schuldig aan cyber- of online criminaliteit, en misschien wel bij uitstek, aangezien zij zijn opgegroeid met ICT (computers, internet en smartphones). Hierbij moet onderscheid worden gemaakt tussen twee vormen (zie Van der Hulst \& Neve 2008; Holt \& Bossler 2014; Van der Laan \& Goudriaan 2016). Aan de ene kant zijn er traditionele delicten waarbij het gebruik van ICT een middel is, zoals online oplichting en bedreiging - deze worden wel aangeduid als 'gedigitaliseerde delicten'. Aan de andere kant zijn er ook 'nieuwe' delicten waarbij ICT niet alleen middel, maar ook doel is, zoals hacken en het verspreiden van virussen.

Recent is over de betrokkenheid van jongeren bij online criminaliteit uitvoerig gerapporteerd in de Monitor Jeugdcriminaliteit (Van der Laan \& Goudriaan 2016), dit op basis van een representatieve steekproef (zie ook de bijdrage van Van der Laan e.a. in dit nummer). Een substantieel percentage van de deelnemende jongeren (31\%) gaf aan in het voorgaande jaar een online delict te hebben gepleegd, variërend van het pesten van leeftijdsgenoten via internet tot online bedreiging, het verspreiden van seksueel getint beeldmateriaal en het inloggen op een computer zonder toestemming. Ook meer geavanceerde online delicten, zoals het uitvoeren van DDoS-aanvallen en het verspreiden van virussen, kwamen voor. Dit sluit aan bij andere onderzoeken 
waaruit blijkt dat een groot deel van de jongeren tegenwoordig ook delicten pleegt via het internet (Kerstens \& Stol 2012; Zebel e.a. 2014; Holt \& Bossler 2014).

Vreemd genoeg zijn deze delicten niet of nauwelijks zichtbaar in de politieregistraties over jeugdcriminaliteit. Zebel e.a. (2014) rapporteren dat zo'n $0,3 \%$ van de geregistreerde jeugdcriminaliteit een online delict is, en zij vinden 166 gevallen in de Onderzoek- en Beleidsdatabase Justitiële Documentatie (OBJD). Van der Laan en Goudriaan (2016) rapporteren minder dan 100 strafzaken voor online criminaliteit onder jongeren en jongvolwassenen in 2014. Waarom online jeugdcriminaliteit nauwelijks zichtbaar wordt in de geregistreerde cijfers is nog onduidelijk. In het verleden is geconstateerd dat niet wordt geregistreerd of een delict online of offline is (Montoya e.a. 2013; Van der Laan \& Goudriaan 2016), of dat aangiften van online criminaliteit niet als zodanig worden opgenomen of ontoereikend worden verwerkt (Leukfeldt e.a. 2013). Waarschijnlijker is dat een groot deel van de online delicten simpelweg niet bekend wordt bij het slachtoffer, of niet wordt herkend of erkend als criminaliteit. Het 'dark number' is bij online delicten waarschijnlijk nog groter dan bij traditionele criminaliteit (De Cuyper \& Weijters 2016).

Het is zeer waarschijnlijk dat de daadwerkelijke online jeugdcriminaliteit onder jongeren sterk is gestegen in de afgelopen jaren. Jongeren zijn zich immers steeds meer gaan begeven op internet, en online activiteiten en social media zijn deel gaan uitmaken van de dagelijkse leefwereld van de meeste jongeren. Met de toename van social media en smartphones, de verdere ontwikkeling van het 'dark web' en allerlei apps is online criminaliteit ook steeds makkelijker uit te voeren en is de verleiding vaker aanwezig om het ook te doen. Als de toename in online criminaliteit gelijke tred heeft gehouden met de opmars van social media en smartphones, is het denkbaar dat er deels een verschuiving heeft plaatsgevonden van offline naar online jeugdcriminaliteit. Het is weliswaar onwaarschijnlijk dat die verschuiving zo groot is dat deze de daling in offline criminaliteit helemaal kan verklaren, maar wellicht draagt die daar wel voor een deel aan bij.

Helaas zijn er op dit moment geen betrouwbare gegevens beschikbaar over eventuele trends in online criminaliteit onder jongeren. In de vorige rondes van de Monitor Jeugdcriminaliteit was er nog niet naar gevraagd in het zelfrapportageonderzoek. We zien geen grote verandering in het aantal geregistreerde online delicten onder jongeren, en de 
aantallen zijn nog steeds zeer gering. Dat betekent echter niet dat er geen sprake kan zijn van een verschuiving. Integendeel, juist doordat zo'n groot deel van de online jeugdcriminaliteit onzichtbaar is in de cijfers, is het waarschijnlijk dat een eventuele verschuiving van de jeugdcriminaliteit van de offline naar de online wereld voor een groot deel wordt gemist door politieregistraties.

\section{Kanttekeningen en slot}

In deze bijdrage is beargumenteerd hoe social media en smartphones een plausibele verklaring kunnen vormen voor de daling in jeugdcriminaliteit. Er zijn opmerkelijke overeenkomsten in het internationale karakter van beide ontwikkelingen en de timing. De ontwikkelingen met betrekking tot ICT en media hebben geleid tot een verandering in de tijdsbesteding van jongeren, waarbij jongeren minder tijd lijken door te brengen met criminogene vormen van langdurig rondhangen op straat. De opkomst van social media heeft geleid tot aanvullende en alternatieve mogelijkheden om in de psychologische en sociale behoeften van adolescenten te voorzien, waardoor veel immateriële motivaties voor het plegen van delicten kunnen zijn weggenomen. De ontwikkelingen hebben ook waarschijnlijk het plegen van online criminaliteit vergemakkelijkt en gestimuleerd, en mogelijk geleid tot een gedeeltelijke verschuiving van offline naar minder zichtbare online jeugdcriminaliteit.

Er zijn echter ook wat kanttekeningen te plaatsen. Ten eerste is niet in alle westerse landen sprake geweest van een daling van de jeugdcriminaliteit die parallel loopt met de opkomst van social media en smartphones. Dat geldt met name voor de Zuid-Europese landen: de daling in Frankrijk is maar gering en in Italië en Spanje is helemaal geen daling zichtbaar. Sommige Centraal-Europese landen laten een fluctuerend beeld zien (zie Eurostat, ec.europa.eu/eurostat/data/ database). Wellicht is de invloed van social media en ICT op de jeugdcriminaliteit minder sterk in deze landen, of wordt deze tegengegaan of geneutraliseerd door iets anders.

Een tweede kanttekening is dat de veronderstelde effecten van social media en ICT niet voor alle jongeren even sterk zullen zijn. Zo zullen er jongeren blijven die door hun thuis- of schoolsituatie veel tijd op straat blijven doorbrengen met rondhangen en 'unstructured sociali- 
zing'. Een toegenomen gebruik van smartphones en social media zal niet veel veranderen aan de vaak ernstige cumulatie van problemen en risicofactoren die ten grondslag liggen aan persistent crimineel gedrag.

Een derde kanttekening is het verschil in de sterkte van de daling tussen geregistreerde en zelfgerapporteerde jeugdcriminaliteit. Dit verschil suggereert dat er registratie-effecten bestaan waardoor de daling in de jeugdcriminaliteit wordt overschat en daarmee ook de invloed van social media en ICT. Aan de andere kant is het ook mogelijk dat het zelfrapportageonderzoek vooral inzicht biedt in de prevalentie van delinquent gedrag in de adolescentiefase, terwijl de politiecijfers vooral worden beïnvloed door ernstiger en meer frequent delinquent gedrag van jongeren.

Tot slot is wellicht de belangrijkste kanttekening dat het nog ontbreekt aan diepgaand en robuust empirisch onderzoek naar de veronderstelde relaties tussen social media en smartphones en jeugdcriminaliteit. We hebben indicaties en parallelle ontwikkelingen, maar die zijn nog niet getoetst tegenover andere mogelijke verklaringen. Bovendien missen we betrouwbare en precieze tijdreeksen over het gebruik van social media en smartphones over meerdere jaren en over de tijdsbesteding van jongeren. Twee typen onderzoek zijn nodig om meer zicht te krijgen op de geldigheid van de veronderstelde relaties en processen. Ten eerste is nader (etiologisch) onderzoek nodig naar de invloed van social media, ICT en smartphones op de individuele betrokkenheid van jongeren bij delinquent gedrag, zowel offline als online, gedurende de adolescentie. Zulk onderzoek zou duidelijk kunnen maken in hoeverre ICT en mediagebruik offline delinquent gedrag nu daadwerkelijk kunnen afremmen en wellicht online criminaliteit stimuleren, en bij wie. Ten tweede is internationaal (comparatief) onderzoek nodig waarin voor meerdere landen wordt nagegaan voor een lange tijdreeks in hoeverre veranderingen in ICT en social media samenhangen met veranderingen in cijfers over jeugdcriminaliteit, onafhankelijk van andere mogelijk verklarende ontwikkelingen op macroniveau.

Vooralsnog moeten we dus nog steeds spreken van een hypothese, die wel zeer plausibel lijkt, maar ook nog nader onderzoek verdient. 


\section{Literatuur}

\section{Bernasco e.a. 2013}

W. Bernasco, S. Ruiter, G.J.N. Bruinsma, L.J.R. Pauwels e.a., 'Situational causes of offending: A fixed effects analysis of spacetime budget data', Criminology (51) 2013, p. 895-926.

\section{Bervoets e.a. 2013}

E. Bervoets, H. Ferwerda, B. Bremmers, D. Keijzer e.a., Daling jeugdige verdachten in Amsterdam. Op zoek naar mogelijke verklaringen, Amsterdam: Reed Business, Politie en Wetenschap 2013.

\section{Van den Broek 2013}

J.B.A. van den Broek, Van de straathoek naar Facebook. Een onderzoek naar het gebruik van sociale media door jongeren binnen de straatcultuur (masterscriptie) Rotterdam 2013.

\section{Van der Bruggen 2015}

M. van der Bruggen, 'Een beschouwing van de ontwikkeling van het internet en cybercriminaliteit en de gevolgen hiervan voor de internationale bestrijding van digitale kinderporno', Tijdschrift voor Criminologie (57) 2015, p. 242-259.

\section{Bucher \& Helmond 2017}

T. Bucher \& A. Helmond, 'The Affordances of Social Media Platforms', in: J. Burgess, Th. Poell \& A., Sage Handbook of social media, Londen: Sage Publishing 2017. www.annehelmond.nl/ 2016/08/01/the-affordances-ofsocial-media-platforms.

\section{CBS 2016}

CBS, ICT, kennis en economie, Den Haag: CBS 2016.

\section{De Cuyper \& Weijters 2016}

R.H. de Cuyper \& G. Weijters, Cybercrime in cijfers (Memorandum 2016-1), Den Haag: WODC 2016.

\section{Deci \& Ryan 1975}

E.L. Deci \& R.M. Ryan, Intrinsic motivation, New York: John

Wiley \& Sons 1975.

\section{Deci \& Ryan 2008}

E.L. Deci \& R.M. Ryan, 'Selfdetermination theory: A macrotheory of human motivation, development, and health', Canadian Psychology (49) 2008, p. 182-185.

\section{Farrell e.a. 2011}

G. Farrell, A. Tseloni, J. Mailley \& N. Tilley, 'The crime drop and the security hypothesis', Journal of Research in Crime and Delinquency (48) 2011, p. 147-175. 


\section{Ferwerda \& Van Ham 2015}

H. Ferwerda \& T. van Ham, Pro-

blematische jeugdgroepen in

Nederland. Omvang en aard in

het najaar van 2014, Arnhem:

Bureau Beke 2015.

\section{Hakkert e.a. 1998}

A. Hakkert, A. van Wijk, H. Ferwerda \& T. Eijken, Groepscriminaliteit. Een terreinverkenning op basis van literatuuronderzoek en een analyse van bestaand onderzoeksmateriaal, aangevuld met enkele interviews met sleutelinformanten en jongeren die tot groepen behoren, Den Haag: Ministerie van Justitie 1998.

\section{Van Ham \& Ferwerda 2016}

T. van Ham \& H. Ferwerda, Van cijfers naar interpretatie. Een duiding van de kwantitatieve ontwikkelingen van de jeugdcriminaliteit, Arnhem: Bureau Beke 2016.

\section{Hazekamp 1985}

J. Hazekamp, Rondhangen als tijdverdrijf: over het onderelkaar-zijn van jongens en meisjes in de vrije tijd, Amsterdam: VU uitgeverij 1985.

\section{Hoeben 2016}

E.M. Hoeben, Hanging out and messing about: Elaborating on the relationship between unstructured socializing and adolescent delinquency (diss. Amsterdam VU), 2016.

\section{Hoeben \& Weerman 2014}

E. Hoeben \& F. Weerman, 'Situational conditions and adolescent offending: Does the impact of unstructured socialising depend on its location?', European Journal of Criminology (11) 2014, p. 481-499.

\section{Holt \& Bossler 2014}

T.J. Holt \& A.M. Bossler, 'An assessment of the current state of cybercrime scholarship', Deviant Behavior (35) 2014, p. 20-40.

\section{Van der Hulst \& Neve 2008}

R.C. van der Hulst \& R.J.M. Neve, High-tech crime, soorten criminaliteit en hun daders, Den Haag: Boom Juridische uitgevers 2008.

\section{Kerstens \& Stol 2012}

J. Kerstens \& W. Stol (red.), Jeugd en cybersafety. Online slachtofferen daderschap onder Nederlandse jongeren, Den Haag: Boom Lemma uitgevers 2012.

\section{Kietzmann e.a. 2011}

J.H. Kietzmann, K. Hermkens, I.P. McCarthy \& B.S. Silvestre, 'Social media? Get serious! Understanding the functional building blocks of social media', Business Horizons (54) 2011, p. 241-251.

\section{Kloosterman \& Beuningen 2015}

R. Kloosterman \& J.V. Beuningen, Jongeren over sociale media, Den Haag: CBS 2015. 
Van der Laan \& Goudriaan 2016

A. van der Laan \& H. Goudriaan, Monitor jeugdcriminaliteit: ontwikkelingen in de jeugdcriminaliteit, 1997-2015, Den Haag:

WODC/CBS 2016.

\section{Van der Laan \& Weijters 2015}

A. van der Laan \& G. Weijters, 'Daling in geregistreerde jeugdcriminaliteit', Tijdschrift voor Criminologie (57) 2015,

p. 203-228.

\section{Leukfeldt e.a. 2013}

R. Leukfeldt, S. Veenstra \&

W. Stol, 'High volume cyber crime and the organization of the police: The results of two empirical studies in the Netherlands', International Journal of Cyber Criminology (7) 2013, p. 1-17.

\section{Montoya e.a. 2013}

L. Montoya, M. Junger \& P. Hartel, How digital is traditional crime?, Conference paper European Intelligence and Security Informatics Conference 2013.

\section{O'Keeffe \& Clarke-Pearson 2011}

G.S. O'Keeffe \& K. Clarke-Pearson, 'The impact of social media on children, adolescents, and families', Pediatrics (127) 2011, p. 800-804.

\section{Osgood \& Anderson 2004}

D.W. Osgood \& A.L. Anderson, 'Unstructured socializing and rates of delinquency', Crimino$\log y$ (42) 2004, p. 519-550.

\section{Osgood e.a. 1996}

D.W. Osgood, J.K. Wilson, P.M.

O'Malley, J.G. Bachman e.a., 'Routine activities and individual deviant behaviour', American Sociological Review (61) 1996, p. 635-655.

\section{Schoenmakers e.a. 2015}

T.M. Schoenmakers, T. van Rooij \& D. van de Mheen, 'Internetgerelateerde verslavingen bij jongeren', Tijdschrift voor gezondheidswetenschappen (93) 2015, p. 61-63.

\section{Sonck \& De Haan 2015}

N. Sonck \& J. de Haan, Media: tijd in beeld. Dagelijkse tijdbesteding aan media en communicatie, Den Haag: SCP 2015.

\section{Tonry 2014}

M. Tonry, 'Why crime rates fall and why they don't', Crime and Justice (43) 2014, p. 1-63.

\section{Turpijn e.a. 2015}

L. Turpijn, S. Kneefel \& N. van der Veer, Nationale social media onderzoek jongeren, Amsterdam/ Enschede: Newcom Research \& Consultancy 2015.

\section{Valkenburg 2014}

P. Valkenburg, Schermgaande jeugd: over jeugd en media, Amsterdam: Prometheus 2014. 


\section{Vollaard e.a. 2009}

B. Vollaard, P. Versteegh \& J. van den Brakel, Veelbelovende verklaringen voor de daling van de criminaliteit na 2002, Tilburg: TILEC, Universiteit van Tilburg 2009.

\section{Warr 1993}

M. Warr, 'Age, peers, and delinquency', Criminology (31) 1993, p. 17-40.

\section{Warr 2002}

M. Warr, Companions in crime. The social aspects of criminal conduct, Cambridge: Cambridge University Press 2002.

\section{Weerman 2001}

F.M. Weerman, Samenplegen. Over criminele samenwerking en groepsvorming, Nijmegen: Ars Aequi Libri 2001.

\section{Weerman e.a. 2015a}

F. Weerman, A. van der Laan, I. Haen Marshall \& L. Pauwels, 'De bestudering van criminaliteit of macroniveau: een inleiding', Tijdschrift voor Criminologie (57) 2015, afl. 2, p. 149-169.

\section{Weerman e.a. 2015b}

F.M. Weerman, W. Bernasco, G.J.N. Bruinsma \& L.J.R. Pauwels, 'When is spending time with peers related to delinquency: The importance of where, what and with whom', Crime \& Delinquency (61) 2015, p. 1386-1413. Zebel e.a. 2014

S. Zebel, P. de Vries, E. Giebels, M. Kuttschreuter e.a , Jeugdige daders van cybercrime in Nederland. Een empirische verkenning, Enschede: Universiteit Twente/ NHL/WODC 2014. 